\title{
Mercury trends in fish from rivers and lakes in the United States, 1969-2005
}

\author{
Ann T. Chalmers • Denise M. Argue • \\ David A. Gay • Mark E. Brigham • \\ Christopher J. Schmitt • David L. Lorenz
}

Received: 4 December 2009 / Accepted: 6 May 2010 / Published online: 10 June 2010

(C) The Author(s) 2010. This article is published with open access at Springerlink.com

\begin{abstract}
A national dataset on concentrations of mercury in fish, compiled mainly from state and federal monitoring programs, was used to evaluate trends in mercury $(\mathrm{Hg})$ in fish from US rivers and lakes. Trends were analyzed on data aggregated by site and by state, using samples of the same fish species and tissue type, and using fish
\end{abstract}

Electronic supplementary material The online version of this article (doi:10.1007/s10661-010-1504-6) contains supplementary material, which is available to authorized users.

\footnotetext{
A. T. Chalmers $(\varangle)$

U.S. Geological Survey, 87 State Street, PO Box 628, Montpelier, VT 06501, USA

e-mail: chalmers@usgs.gov

D. M. Argue

U.S. Geological Survey, 331 Commerce Way,

Pembroke, NH 03275-3718, USA

D. A. Gay

NADP Program Office, Illinois State Water Survey, 2204 Griffith Drive, Champaign, IL 61820, USA

M. E. Brigham · D. L. Lorenz

U.S. Geological Survey, 2280 Woodale Drive,

Mounds View, MN 55112, USA

C. J. Schmitt

U.S. Geological Survey,

Columbia Environmental Research Center,

4200 New Haven Road, Columbia,

MO 65201, USA
}

of similar lengths. Site-based trends were evaluated from 1969 to 2005, but focused on a subset of the data from 1969 to 1987. Data aggregated by state were used to evaluate trends in fish $\mathrm{Hg}$ concentrations from 1988 to 2005. In addition, the most recent $\mathrm{Hg}$ fish data (1996-2005) were compared to wet $\mathrm{Hg}$ deposition data from the Mercury Deposition Network (MDN) over the same period. Downward trends in $\mathrm{Hg}$ concentrations in fish from data collected during 1969-1987 exceeded upward trends by a ratio of 6 to 1 . Declining $\mathrm{Hg}$ accumulation rates in sediment and peat cores reported by many studies during the 1970 s and 1980s correspond with the period when the most downward trends in fish $\mathrm{Hg}$ concentrations occurred. Downward $\mathrm{Hg}$ trends in both sediment cores and fish were also consistent with the implementation of stricter regulatory controls of direct releases of $\mathrm{Hg}$ to the atmosphere and surface waters during the same period. The southeastern USA had more upward $\mathrm{Hg}$ trends in fish than other regions for both site and state aggregated data. Upward $\mathrm{Hg}$ trends in fish from the southeastern USA were associated with increases in wet deposition in the region and may be attributed to a greater influence of global atmospheric $\mathrm{Hg}$ emissions in the southeastern USA. No significant trends were found in $62 \%$ of the fish species from six states from 1996 to 2005. A lack of $\mathrm{Hg}$ trends in fish in the more recent data was consistent with the lack of trends in wet $\mathrm{Hg}$ deposition at MDN 
sites and with relatively constant global emissions during the same time period. Although few significant trends were observed in the more recent $\mathrm{Hg}$ concentrations in fish, it is anticipated that $\mathrm{Hg}$ concentrations in fish will respond to changes in atmospheric $\mathrm{Hg}$ deposition, however, the magnitude and timing of the response is uncertain.

Keywords Mercury • Fish • Trends • Wet deposition - Atmospheric emissions

\section{Introduction}

Mercury $(\mathrm{Hg})$ is a ubiquitous environmental pollutant that accumulates to harmful concentrations in aquatic ecosystems. Atmospheric deposition is the dominant source of inorganic $\mathrm{Hg}$ in many aquatic ecosystems (Fitzgerald et al. 1998; Downs et al. 1998; Wiener et al. 2006; Peterson et al. 2007). Industrial and municipal point-sources of mercury to rivers and lakes were very important historically, but have been greatly reduced since the implementation of stricter regulatory controls in the 1970s (Balogh et al. 1999; Krabbenhoft et al. 2005). Widespread $\mathrm{Hg}$ contamination of fish in remote areas with low rates of $\mathrm{Hg}$ deposition suggests $\mathrm{Hg}$ loading in an ecosystem alone does not define $\mathrm{Hg}$ concentration in fish (Krabbenhoft et al. 2005; Wiener et al. 2007). Transport of atmospheric $\mathrm{Hg}$ to aquatic ecosystems and $\mathrm{Hg}$ cycling within aquatic systems are complex and not fully understood. Catchment size, geochemistry, hydrology, climate, soil, land-use, land cover, and topography all influence delivery of $\mathrm{Hg}$ to aquatic ecosystems (Balogh et al. 1999). Human activities contribute atmospheric emissions and direct point source $\mathrm{Hg}$ contamination, and create land disturbances that enhance $\mathrm{Hg}$ delivery to aquatic ecosystems (Balogh et al. 1999).

Methylation of inorganic atmospheric $\mathrm{Hg}$ to monomethylmercury ( $\mathrm{MeHg}$ ), which bioaccumulates and biomagnifies in fish, is in turn influenced by a variety of environmental factors such as organic carbon availability, pH, sulfur cycling, biological productivity, and temperature (Wiener et al. 2006). Fish are probably the most widely studied component of $\mathrm{Hg}$ transfer and bioaccumulation in ecosystems because fish consump- tion is the main $\mathrm{Hg}$ exposure pathway for humans and wildlife. The $\mathrm{Hg}$ concentration in fish, which is generally assumed to be $>95 \% \mathrm{MeHg}$ (Bloom 1992), ultimately depends on the availability of $\mathrm{MeHg}$ in their diet and the degree to which the fish can excrete $\mathrm{Hg}$ (Downs et al. 1998). Fish $\mathrm{Hg}$ concentrations vary by species due to food web position and biochemical differences among species (Wiener et al. 2003). Hg typically accumulates in fish as their age and size increases due to relative exposure times and food web position (Downs et al. 1998; Chen and Folt 2005). Variability in fish $\mathrm{Hg}$ concentrations can be reduced by controlling for fish species and fish age or length (Wiener et al. 2007). Many federal, state, and local agencies are monitoring $\mathrm{Hg}$ in fish to identify areas with fish $\mathrm{Hg}$ concentrations of concern to human health. Elevated $\mathrm{Hg}$ concentrations in fish represent a public health hazard and the primary reason for $80 \%$ of the 3,080 fish consumption advisories issued by 48 states in 2006 (http://www.epa.gov/waterscience/ fish/advisories/2006/tech.pd).

Datasets of $\mathrm{Hg}$ concentrations in fish collected by federal, state, and local agencies were compiled by the USGS Geographic Analysis and Monitoring program and the National Institute of Environmental Health Sciences to be used by environmental and health researchers in investigations of $\mathrm{Hg}$ in the environment. The result of this effort was the Environmental Mercury Mapping, Modeling, and Analysis (EMMMA) database (http://emmma.usgs.gov/, accessed 30 October 2007). As of 2007, the EMMMA dataset included 74,867 records from 7,759 sites collected by 27 agencies from 1969 to 2005. Samples included both rivers (5,034 sites) and lakes (2,725 sites). Fish data were compiled from every state except Hawaii. The EMMMA database contains 241 fish species and 14 types of tissues. The objectives of this paper are (1) to assess whether EMMMA data can provide evidence of changes in $\mathrm{Hg}$ concentrations in fish in the USA between 1969 and 2005 and (2) to compare fish $\mathrm{Hg}$ trends to trends in $\mathrm{Hg}$ wet deposition and $\mathrm{Hg}$ atmospheric emissions. Substantial additional data may exist in state, federal, and other databases; however, additional efforts to compile data were beyond the scope of this paper. 


\section{Methods}

Trend analyses

Trends were analyzed on 31 different fish species and three tissue types. Each trend analysis was limited to one fish species and tissue type. A restricted range of fish lengths were used to normalize data for differences in fish age and size. Data within $10 \%$ of the median length for each species and tissue type were retained for trend analyses. Trends were analyzed on data aggregated by site and by state. Sites were selected for trend evaluation if they had at least seven fish samples within the restricted range of fish lengths that were of the same species and tissue type collected for at least different 5 years over more than a 10 -year period between 1969 and 2005. Ninety of the original 7,759 river and lake sites met the criteria for trend analyses (Table 1; Supplemental Table A). Site trends focused on a subset of 50 of the 90 sites having data in the period 1969-1987 (Table 2).

Statewide trends were analyzed on an aggregate of all samples of a single fish species and tissue type from a state that met the following criteria: during the period 1988-2005, fish samples of one species and tissue type within the restricted length were collected for at least seven different years for over at least a 10 -year period. In addi- tion, for each fish species and tissue type evaluated in the statewide trend, at least 30 sites had to have been sampled in the state over the 10-year period, with at least three sites having been sampled in both the first and last years of sample collection. Statewide trends were not analyzed prior to 1988 because of insufficient data. Statewide trends were also analyzed from 1996 to 2005 using the same statewide criteria except that the period of record was reduced to at least five different years over at least a 6-year period between 1996 and 2005. The results of the fish $\mathrm{Hg}$ trend analyses from 1996-2005 provide a direct comparison with $\mathrm{Hg}$ wet deposition data that the National Atmospheric Deposition Program Mercury Deposition Network (NADP MDN) began collecting in 1995.

The EMMMA dataset had no information about the sampling or analytical methods used by the 27 agencies that provided data. Changes or differences in sampling or analytical methods in this dataset can result in false trends. Differences in methods used by each agency were minimized by aggregating data by site and by state. Data from most sites and states were collected by only one agency.

Statistical analysis was performed using Version 9.1.3 of the Statistical Analysis System (SAS Institute 2002). Trends were determined through the use of the SAS LIFEREG (linear regression)

Table 1 Summary of trend data aggregated by site and by state

\begin{tabular}{|c|c|c|c|c|}
\hline \multirow{2}{*}{$\frac{\text { Data aggregation }}{\text { Period }}$} & \multicolumn{2}{|l|}{ Site } & \multicolumn{2}{|l|}{ State } \\
\hline & 1969-2005 & 1969-1987 & 1988-2005 & 1996-2005 \\
\hline Sites $(n)$ & 90 & 50 & 2,609 & 2,801 \\
\hline States $(n)$ & 32 & 31 & 8 & 6 \\
\hline Major sources of data & $\begin{array}{l}\text { State and federal } \\
\text { programs }\end{array}$ & $\begin{array}{l}\text { National Contaminant } \\
\text { Biomonitoring Program }\end{array}$ & State programs & State programs \\
\hline $\begin{array}{l}\mathrm{Hg} \text { concentrations } \\
\text { in fish }(\mu \mathrm{g} / \mathrm{g})\end{array}$ & $<0.01-2.6$ & $<0.01-1.2$ & $<0.001-4.8$ & $<0.001-4.8$ \\
\hline $\begin{array}{l}\text { Median } \mathrm{Hg} \text { concentration } \\
\text { in fish }(\mu \mathrm{g} / \mathrm{g})\end{array}$ & 0.23 & 0.10 & 0.22 & 0.24 \\
\hline \multirow[t]{2}{*}{ Dominant fish species } & Common carp & Common carp & Largemouth bass & Largemouth bass \\
\hline & Largemouth bass & White sucker & Channel catfish & Channel catfish \\
\hline Fish species $(n)$ & 26 & 21 & 12 & 14 \\
\hline $\begin{array}{l}\text { Upper trophic level } \\
\text { species (\%) }\end{array}$ & 50 & 26 & 73 & 73 \\
\hline Tissue type & $\begin{array}{l}\text { Whole fish, skin-on } \\
\text { and skin-off fillets }\end{array}$ & Whole fish & $\begin{array}{l}\text { Skin-on and } \\
\text { skin-off fillets }\end{array}$ & $\begin{array}{l}\text { Skin-on and } \\
\text { skin-off fillets }\end{array}$ \\
\hline
\end{tabular}

Site-specific data analysis focused on a subset of data from 1969 to 1987. Statewide data were analyzed over one shorter period, 1996-2005, for a direct comparison with wet $\mathrm{Hg}$ deposition data 
Table 2 Trends in $\mathrm{Hg}$ concentrations in whole fish from 1969 to 1987 at 50 National Contaminant Biomonitoring Program sites

\begin{tabular}{|c|c|c|c|c|c|c|c|c|c|}
\hline Site & Site name & State & Species & $n$ & $\begin{array}{l}\text { Begin } \\
\text { year }\end{array}$ & $\begin{array}{l}\text { End } \\
\text { year }\end{array}$ & $\begin{array}{l}\mathrm{Hg}(\mu \mathrm{g} / \mathrm{g}) \\
\text { median }\end{array}$ & $p$ value & $\begin{array}{l}\text { Percent } \\
\text { change }\end{array}$ \\
\hline 1 & $\begin{array}{l}\text { Apalachicola River, } \\
\text { J Woodruff Dam }\end{array}$ & FL & SS & 13 & 1969 & 1986 & 0.11 & 0.135 & -2.11 \\
\hline 2 & Arkansas River & AR & $\mathrm{CC}$ & 9 & 1969 & 1984 & 0.08 & 0.004 & -5.92 \\
\hline 3 & Chena River & $\mathrm{AK}$ & LNS & 8 & 1969 & 1981 & 0.08 & 0.402 & 2.41 \\
\hline 4 & $\begin{array}{l}\text { Columbia River, } \\
\text { Cascade Locks }\end{array}$ & OR/WA & LSS & 10 & 1969 & 1984 & 0.15 & 0.005 & -9.06 \\
\hline 5 & $\begin{array}{l}\text { Connecticut River, } \\
\text { Windsor locks }\end{array}$ & $\mathrm{CT}$ & WCF & 12 & 1969 & 1984 & 0.15 & 0.000 & -7.22 \\
\hline 6 & Delaware River & $\mathrm{NJ} / \mathrm{PA}$ & WS & 12 & 1969 & 1984 & 0.06 & 0.050 & -4.59 \\
\hline 7 & Hudson River & NY & G & 10 & 1969 & 1980 & 0.13 & 0.414 & -2.89 \\
\hline 8 & Illinois River & IL & $\mathrm{CC}$ & 13 & 1969 & 1986 & 0.06 & 0.255 & -1.49 \\
\hline 9 & Klamath River & $\mathrm{CA}$ & YP & 7 & 1969 & 1986 & 0.19 & 0.000 & -3.31 \\
\hline 10 & Lake Erie & PA & YP & 11 & 1969 & 1986 & 0.09 & 0.000 & -8.23 \\
\hline 11 & Lake Huron & MI & $\mathrm{CC}$ & 14 & 1969 & 1986 & 0.06 & 0.206 & 3.11 \\
\hline 11 & Lake Huron & MI & YP & 10 & 1969 & 1986 & 0.08 & 0.221 & 4.68 \\
\hline 12 & Lake Ontario & $N Y$ & $R B$ & 7 & 1969 & 1981 & 0.36 & 0.000 & -10.36 \\
\hline 13 & Lake Superior & WI & $\mathrm{BL}$ & 10 & 1969 & 1986 & 0.11 & 0.000 & -5.36 \\
\hline 13 & Lake Superior & WI & LT & 7 & 1969 & 1986 & 0.26 & 0.082 & -3.52 \\
\hline 14 & $\begin{array}{l}\text { Missouri River, } \\
\text { Garrison Dam }\end{array}$ & ND & $\mathrm{W}$ & 7 & 1969 & 1986 & 0.20 & 0.081 & -2.74 \\
\hline 15 & Red River of the North & $M N / N D$ & $S$ & 9 & 1969 & 1986 & 0.45 & 0.001 & -4.86 \\
\hline 16 & Penobscot River & $M E$ & $W S$ & 13 & 1969 & 1986 & 0.25 & 0.001 & -4.71 \\
\hline 17 & Rio Grande & $\mathrm{TX}$ & GS & 9 & 1969 & 1986 & 0.05 & 0.004 & -5.69 \\
\hline 18 & Sacramento River & $\mathrm{CA}$ & $\mathrm{CC}$ & 7 & 1969 & 1986 & 0.10 & 0.001 & -7.13 \\
\hline 19 & Salmon River & ID & LSS & 7 & 1969 & 1986 & 0.19 & 0.179 & -4.88 \\
\hline 20 & Snake River & ID/WA & LSS & 13 & 1969 & 1986 & 0.11 & 0.679 & 0.95 \\
\hline 21 & Utah Lake & UT & $\mathrm{CC}$ & 10 & 1969 & 1986 & 0.04 & 0.396 & 2.65 \\
\hline 21 & Utah Lake & UT & WB & 8 & 1969 & 1986 & 0.06 & 0.588 & 1.85 \\
\hline 22 & White River & AR & $\mathrm{BMBU}$ & 8 & 1969 & 1986 & 0.24 & 0.009 & 7.66 \\
\hline 23 & Yakima River & WA & LSS & 8 & 1969 & 1986 & 0.08 & 0.362 & -3.26 \\
\hline 24 & $\begin{array}{l}\text { Verdigris River, } \\
\text { Bartlesville Reservoir }\end{array}$ & $\mathrm{OK}$ & $\mathrm{CC}$ & 10 & 1970 & 1986 & 0.06 & 0.765 & -0.60 \\
\hline 25 & Columbia River & WA & $\mathrm{CC}$ & 8 & 1970 & 1980 & 0.06 & 0.051 & -8.66 \\
\hline 26 & Cumberland River & $\mathrm{TN}$ & $\mathrm{CC}$ & 9 & 1970 & 1986 & 0.08 & 0.125 & -1.65 \\
\hline 27 & $\begin{array}{l}\text { Colorado River, } \\
\text { Imperial Reservoir }\end{array}$ & $\mathrm{AZ} / \mathrm{CA}$ & $\mathrm{CC}$ & 10 & 1970 & 1984 & 0.01 & 0.001 & 6.36 \\
\hline 28 & James River & SD & $\mathrm{CC}$ & 10 & 1970 & 1986 & 0.09 & 0.453 & -1.09 \\
\hline 28 & James River & SD & GE & 8 & 1971 & 1986 & 0.18 & 0.677 & 1.82 \\
\hline 29 & Kennebec River & $\mathrm{ME}$ & WS & 7 & 1971 & 1984 & 0.16 & 0.091 & -1.49 \\
\hline 29 & Kennebec River & $M E$ & $Y P$ & 10 & 1970 & 1986 & 0.50 & 0.000 & -9.13 \\
\hline 30 & Lake Michigan & WI & $\mathrm{BL}$ & 14 & 1970 & 1986 & 0.05 & 0.003 & -5.75 \\
\hline 30 & Lake Michigan & $W I$ & $L T$ & 7 & 1971 & 1986 & 0.14 & 0.000 & -10.26 \\
\hline 31 & $\begin{array}{l}\text { Colorado River, } \\
\text { Lake Powell }\end{array}$ & $\mathrm{AZ}$ & $\mathrm{CC}$ & 13 & 1971 & 1986 & 0.12 & 0.270 & -1.52 \\
\hline 31 & $\begin{array}{l}\text { Colorado River, } \\
\text { Lake Powell }\end{array}$ & $\mathrm{AZ}$ & LMB & 7 & 1970 & 1984 & 0.18 & 0.126 & -3.34 \\
\hline 32 & Mississippi River & IA/WI & $\mathrm{CC}$ & 9 & 1970 & 1984 & 0.10 & 0.213 & -3.82 \\
\hline 33 & Missouri River & NE/IA & $\mathrm{CC}$ & 13 & 1970 & 1986 & 0.06 & 0.596 & -1.78 \\
\hline 33 & Missouri River & NE/IA & GE & 7 & 1970 & 1981 & 0.10 & 0.000 & -10.32 \\
\hline
\end{tabular}


Table 2 (continued)

\begin{tabular}{|c|c|c|c|c|c|c|c|c|c|}
\hline Site & Site name & State & Species & $n$ & $\begin{array}{l}\text { Begin } \\
\text { year }\end{array}$ & $\begin{array}{l}\text { End } \\
\text { year }\end{array}$ & $\begin{array}{l}\mathrm{Hg}(\mu \mathrm{g} / \mathrm{g}) \\
\text { median }\end{array}$ & $p$ value & $\begin{array}{l}\text { Percent } \\
\text { change }\end{array}$ \\
\hline 34 & $\begin{array}{l}\text { North Platte River, } \\
\text { Lake McConaughy }\end{array}$ & $\mathrm{NE}$ & $\mathrm{CC}$ & 9 & 1970 & 1986 & 0.10 & 0.087 & -3.21 \\
\hline 34 & $\begin{array}{l}\text { North Platte River, } \\
\text { Lake McConaughy }\end{array}$ & $\mathrm{NE}$ & $\mathrm{W}$ & 8 & 1970 & 1986 & 0.08 & 0.011 & -7.37 \\
\hline 35 & Nueces River & $\mathrm{TX}$ & GS & 10 & 1970 & 1986 & 0.02 & 0.043 & 2.47 \\
\hline 36 & $\begin{array}{l}\text { Red River, } \\
\text { Lake Texoma }\end{array}$ & OK/TX & $\mathrm{CC}$ & 9 & 1970 & 1986 & 0.09 & 0.962 & 0.19 \\
\hline 37 & $\begin{array}{l}\text { Rogue River, } \\
\text { Goldray Dam }\end{array}$ & $O R$ & $B B$ & 10 & 1970 & 1986 & 0.12 & 0.000 & -11.98 \\
\hline 38 & Wisconsin River & WI & $\mathrm{CC}$ & 10 & 1970 & 1986 & 0.17 & 0.003 & -4.78 \\
\hline 39 & Yazoo River & MS & SMBU & 8 & 1970 & 1986 & 0.17 & 0.703 & 0.49 \\
\hline 40 & Green River & UT & $\mathrm{CC}$ & 10 & 1971 & 1986 & 0.11 & 0.082 & 2.53 \\
\hline 41 & Mississippi River & $\mathrm{MN}$ & WS & 9 & 1971 & 1986 & 0.23 & 0.760 & -1.29 \\
\hline 42 & Ohio River & IL/KY & $\mathrm{CC}$ & 8 & 1971 & 1984 & 0.14 & 0.000 & -5.64 \\
\hline 43 & Ohio River & $\mathrm{OH} / \mathrm{KY}$ & $\mathrm{CC}$ & 9 & 1971 & 1987 & 0.06 & 0.006 & -3.56 \\
\hline 44 & Raritan River & NJ & WS & 9 & 1971 & 1986 & 0.18 & 0.032 & 3.46 \\
\hline 45 & Rio Grande & $\mathrm{CO}$ & WS & 7 & 1971 & 1986 & 0.03 & 0.000 & -6.31 \\
\hline 46 & St. Lawrence River & NY & WS & 7 & 1971 & 1987 & 0.11 & 0.770 & -1.02 \\
\hline 47 & $\begin{array}{l}\text { Susquehanna River, } \\
\text { Conowingo Dam }\end{array}$ & MD & $\mathrm{CC}$ & 7 & 1971 & 1986 & 0.08 & 0.000 & -5.37 \\
\hline 48 & Wabash River & IN/IL & $\mathrm{CC}$ & 8 & 1971 & 1986 & 0.15 & 0.002 & -4.59 \\
\hline 49 & Des moines River & IA & $\mathrm{CC}$ & 11 & 1972 & 1986 & 0.07 & 0.041 & 6.34 \\
\hline 50 & $\begin{array}{l}\text { Cooper River, } \\
\text { Lake Moultrie }\end{array}$ & $\mathrm{SC}$ & $\mathrm{CCF}$ & 8 & 1976 & 1986 & 0.04 & 0.208 & 3.14 \\
\hline
\end{tabular}

Significant trends $(p<0.05)$ are shaded. Downward trends starting above and ending below EPA advisory guideline $(0.3 \mu \mathrm{g} / \mathrm{g} \mathrm{MeHg})$ are in italics. All other trends are below EPA guideline

$B M B U$ bigmouth buffalo, $B L$ bloater, $B B$ brown bullhead, $C C F$ channel catfish, $C C$ common carp, $G S$ gizzard shad, $G E$ goldeye, $G$ goldfish, $L T$ lake trout, $L M B$ largemouth bass, $L S S$ largescale sucker, $L N S$ longnose sucker, $R B$ rock bass, $S$ sauger, $S M B U$ smallmouth buffalo, $S S$ spotted sucker, $W$ walleye, $W B$ white bass, $W C F$ white catfish, $W S$ white sucker, $Y P$ yellow perch

procedure, which yields estimates of parametric regression models for censored data using the method of maximum likelihood (Allison 1995). $\mathrm{Hg}$ concentrations in fish were natural log transformed to remove much of the heterogeneity of residuals. Linear changes in $\log \mathrm{Hg}$ concentrations were considered significant if the $p$ value was less than 0.05. Three diagnostic statistics, Cook's $\mathrm{D}$, leverage, and standardized residual statistics were used to identify data values that substantially influenced the fit of the regression line (Helsel and Hirsch 1992). Data values that diagnostic statistics identified as outliers were removed resulting in changes in trends at two sites. The annual percent change in fish $\mathrm{Hg}$ concentrations was calculated using the equation, $\left(e^{B}-1\right) \times 100$, where $B$ is the slope of the regression line (Hirsch et al. 1991).

\section{Ancillary data}

Ancillary data were obtained for the 90 sites that met the trends criteria. Land use, land cover, and watershed size were compiled for each of the trend site watersheds from the National Hydrography Dataset Plus (NHDPlus; USEPA 2006; U. S. Geological Survey 2000). NHDPlus is a compilation of geospatial data that includes features from the National Hydrography Dataset, the National Elevation Dataset, and the National Watershed Boundary Dataset.

\section{Dataset compositions}

The 1969-2005 trends data aggregated by site consists of 80 river sites and 10 lake sites. However, 
13 of the river sites were at impoundments, where conditions were more similar to a reservoir or lake than a river (Supplemental Table A). Fourteen rivers had more than one site and 14 sites had more than one species of fish that met the trend analyses criteria. The average length of record at the sites was 17 years, and the maximum 29 years (Supplemental Table A). The 90 sites were located in 32 states; however, 20 of the 90 sites were in South Carolina. Two data sources provided $82 \%$ of the data-the National Contaminant Biomonitoring Program (NCBP; 54 sites), and the South Carolina Department of Health and Environmental Conservation (ScDHEC; 20 sites).

The NCBP analyzed $\mathrm{Hg}$ concentrations in whole fish at 117 sites on large rivers and lakes across the USA from 1969 through 1987 (May and McKinney 1981; Lowe et al. 1985; Schmitt and Brumbaugh 1990; Schmitt et al. 1999). The Biomonitoring of Environmental Status and Trends (BEST) program, an extension and revision of the NCBP, collected additional samples at selected NCBP sites in the Mississippi River and Columbia River basins during 1995 and 1997, respectively (Schmitt et al. 2005; Hinck et al. 2006a). Of the original 117 NCBP sites, 54 met our criteria for trends analyses from 1969 to 2005, and 50 of the sites met criteria for trends analysis from 1969 to 1987 . More than half the fish collected by the NCBP at the 54 sites were from the lower trophic level, mainly common carp (Cyprinus carpio, $34 \%$ ) and sucker species (Catostomus sp., 23\%).

Table 3 Trends in $\mathrm{Hg}$ concentrations based on fish data aggregated by state from 1988 to 2005

\begin{tabular}{|c|c|c|c|c|c|c|c|c|c|}
\hline State & Sites & $n$ & Species & $\begin{array}{l}\text { Begin } \\
\text { year }\end{array}$ & $\begin{array}{l}\text { End } \\
\text { year }\end{array}$ & $\begin{array}{l}\text { Median } \\
\mathrm{Hg}(\mu \mathrm{g} / \mathrm{g})\end{array}$ & $p$ value & $\begin{array}{l}\text { Percent } \\
\text { change }\end{array}$ & Trend \\
\hline \multicolumn{10}{|c|}{ Southeastern USA } \\
\hline GA & $\underline{112}$ & 266 & $\underline{\mathrm{LMB}}$ & 1991 & 2001 & $\underline{0.24}$ & $\leq 0.001$ & 7.43 & $\underline{\mathrm{UP}}$ \\
\hline GA & 56 & 105 & $\mathrm{CCF}$ & 1991 & 2001 & 0.10 & 0.063 & 6.76 & NONE \\
\hline$\underline{\mathrm{LA}}$ & $\underline{324}$ & 1,049 & $\underline{\mathrm{LMB}}$ & 1994 & 2005 & 0.39 & $<0.001$ & $\underline{3.78}$ & $\underline{\mathrm{UP}}$ \\
\hline LA & 113 & 168 & $\mathrm{CCF}$ & 1994 & 2004 & 0.10 & 0.007 & 11.2 & UP \\
\hline$\underline{\mathrm{LA}}$ & $\underline{178}$ & $\underline{328}$ & $\underline{F D}$ & $\underline{1994}$ & 2004 & $\underline{0.37}$ & $\underline{0.013}$ & $\underline{6.23}$ & $\underline{\mathrm{UP}}$ \\
\hline$\overline{\mathrm{LA}}$ & 72 & 125 & $\mathrm{RS}$ & 1994 & 2004 & $\overline{0.16}$ & 0.075 & 11.4 & NONE \\
\hline LA & 158 & 383 & WC & 1994 & 2004 & 0.21 & 0.601 & 1.14 & NONE \\
\hline LA & 178 & 378 & $\mathrm{BC}$ & 1995 & 2005 & 0.24 & 0.686 & 0.83 & NONE \\
\hline $\mathbf{L A}$ & 169 & 444 & B & 1994 & 2005 & 0.52 & 0.019 & -3.26 & DOWN \\
\hline$L A$ & 42 & 66 & $B M B U$ & 1995 & 2004 & 0.28 & 0.045 & -6.66 & $D O W N$ \\
\hline $\mathrm{NC}$ & 37 & 61 & BG & 1989 & 1999 & 0.10 & 0.771 & 0.76 & NONE \\
\hline SC & 129 & 963 & B & 1993 & 2004 & 0.80 & 0.003 & 3.02 & UP \\
\hline $\mathrm{SC}$ & 70 & 194 & $\mathrm{CCF}$ & 1994 & 2004 & $<0.25$ & 0.277 & -2.29 & NONE \\
\hline $\mathbf{S C}$ & 188 & 1,556 & LMB & 1993 & 2004 & 0.38 & $<0.001$ & -3.13 & DOWN \\
\hline \multicolumn{10}{|c|}{ Midwestern USA } \\
\hline IA & 31 & 34 & LMB & 1994 & 2005 & 0.13 & 0.947 & 0.25 & NONE \\
\hline IA & 44 & 60 & $\mathrm{CC}$ & 1993 & 2005 & 0.10 & 0.005 & -6.11 & DOWN \\
\hline IA & 87 & 142 & $\mathrm{CCF}$ & 1988 & 2005 & 0.09 & $<0.001$ & -6.14 & DOWN \\
\hline IN & 194 & 285 & $\mathrm{CC}$ & 1988 & 2004 & 0.17 & 0.856 & -0.11 & NONE \\
\hline IN & 56 & 74 & $\mathrm{CCF}$ & 1988 & 2004 & 0.14 & 0.316 & -1.04 & NONE \\
\hline IN & 75 & 91 & LMB & 1991 & 2004 & 0.19 & 0.999 & 0.00 & NONE \\
\hline MI & 55 & 158 & LMB & 1988 & 1997 & 0.31 & 0.632 & -0.75 & NONE \\
\hline $\mathrm{MN}$ & 43 & 81 & $\mathrm{CCF}$ & 1990 & 2000 & 0.21 & 0.364 & 1.80 & NONE \\
\hline $\mathrm{MN}$ & 78 & 157 & $\mathrm{CC}$ & 1990 & 2001 & 0.13 & 0.085 & -2.16 & NONE \\
\hline$M N$ & 53 & 142 & $N P$ & 1988 & 2001 & 0.27 & 0.001 & -4.89 & DOWN \\
\hline $\mathrm{MN}$ & 75 & 202 & $\mathrm{~W}$ & 1989 & 2001 & 0.23 & 0.036 & -3.16 & DOWN \\
\hline
\end{tabular}

Significant trends $(p$ value $<0.05)$ are shaded. Trends above EPA advisory guideline $(0.3 \mu \mathrm{g} / \mathrm{g} \mathrm{MeHg})$ are in bold text. Upward trends starting below and ending above EPA guideline are underlined. Downward trends starting above and ending below EPA guideline are in italics. Trends below EPA guideline are in regular text

$B M B U$ bigmouth buffalo, $B C$ black crappie, $B G$ bluegill, $B$ bowfin, $C C F$ channel catfish, $C C$ common carp, $F D$ freshwater drum, $L M B$ largemouth bass, $N P$ northern pike, $R S$ redear sunfish, $W$ walleye, $W C$ white crappie 
The latter included white (Catostomus commersonii), largescale (Catostomus macrocheilus), and longnose (Catostomus catostomus) suckers.

The ScDHEC collected fish samples at 201 sites from 1992 to 2005. Of the 20 ScDHEC sites that met our criteria for trend analyses, more than $90 \%$ of the fish were upper trophic level species, predominantly largemouth bass $(\mathrm{Mi}$ cropterus salmoides; 63\%) and bowfin (Amia calva; $22 \%$ ). Although median $\mathrm{Hg}$ concentrations in fish from ScDHEC sites were five times higher than at NCBP sites, $24 \%$ of samples were below the ScDHEC $\mathrm{Hg}$ detection level of $0.25 \mu \mathrm{g} / \mathrm{g}$.
In contrast, only $2 \%$ of NCBP samples were below detection levels, which ranged from 0.05 to $0.01 \mu \mathrm{g} / \mathrm{g}$. The watersheds of the ScDHEC sites were roughly one-tenth the size of NCBP watersheds, but the median percent wetlands were 10 times higher in the ScDHEC watersheds than in the NCBP watersheds (Supplemental Table B). Biases in the data may result from over-representation of sites in South Carolina because of the higher percentage of wetlands in their watersheds and their relatively high $\mathrm{Hg}$ concentration when compared to other trend sites. High amounts of wetlands in South Carolina wa-

Table 4 Trends in Hg concentrations based on fish data aggregated by state between 1996 and 2005

\begin{tabular}{|c|c|c|c|c|c|c|c|c|c|}
\hline State & Sites & $n$ & Species & $\begin{array}{l}\text { Begin } \\
\text { year }\end{array}$ & $\begin{array}{l}\text { End } \\
\text { year }\end{array}$ & $\begin{array}{l}\text { Median } \\
\mathrm{Hg}(\mu \mathrm{g} / \mathrm{g})\end{array}$ & $p$ value & $\begin{array}{l}\text { Percent } \\
\text { change }\end{array}$ & Trend \\
\hline \multicolumn{10}{|c|}{ Southeastern USA } \\
\hline GA & 41 & 53 & $\mathrm{CCF}$ & 1996 & 2001 & 0.11 & 0.303 & 11.7 & NONE \\
\hline GA & 88 & 174 & LMB & 1996 & 2001 & 0.30 & 0.399 & -3.28 & NONE \\
\hline LA & 102 & 151 & $\mathrm{CCF}$ & 1996 & 2004 & 0.10 & 0.002 & 14.9 & UP \\
\hline$\underline{\mathrm{LA}}$ & $\underline{53}$ & $\underline{74}$ & $\underline{\mathrm{FCF}}$ & $\underline{1996}$ & $\underline{2004}$ & $\underline{0.32}$ & $\underline{0.005}$ & $\underline{15.1}$ & $\underline{\mathrm{UP}}$ \\
\hline$\overline{\mathbf{L A}}$ & $\overline{316}$ & $9 \overline{988}$ & $\overline{L M B}$ & 1996 & $\overline{2005}$ & 0.39 & 0.003 & 3.10 & $\overline{\mathbf{U P}}$ \\
\hline LA & 62 & 97 & $\mathrm{RS}$ & 1996 & 2004 & 0.16 & 0.057 & 15.0 & NONE \\
\hline LA & 112 & 193 & $\mathrm{BCF}$ & 1996 & 2004 & 0.14 & 0.056 & 7.30 & NONE \\
\hline LA & 175 & 318 & $\mathrm{FD}$ & 1996 & 2004 & 0.37 & 0.223 & 3.03 & NONE \\
\hline LA & 173 & 373 & $\mathrm{BC}$ & 1996 & 2004 & 0.24 & 0.485 & 1.47 & NONE \\
\hline LA & 153 & 367 & WC & 1996 & 2004 & 0.21 & 0.571 & -1.27 & NONE \\
\hline LA & 42 & 63 & BMBU & 1996 & 2004 & 0.28 & 0.085 & -6.49 & NONE \\
\hline $\mathbf{L A}$ & 169 & 434 & B & 1996 & 2005 & 0.52 & 0.011 & -3.79 & DOWN \\
\hline SC & 128 & 922 & B & 1996 & 2004 & 0.79 & $<0.001$ & 5.50 & $\mathbf{U P}$ \\
\hline$\underline{\mathrm{SC}}$ & $\underline{51}$ & $\underline{179}$ & $\underline{\mathrm{BCF}}$ & $\underline{1996}$ & $\underline{2004}$ & $\leq 0.25$ & $\underline{0.001}$ & $\underline{9.06}$ & $\underline{\mathrm{UP}}$ \\
\hline$\overline{\mathrm{SC}}$ & $\overline{143}$ & 963 & $\mathrm{RS}$ & 1996 & 2004 & $<0.25$ & 0.006 & 3.38 & $\overline{\mathrm{UP}}$ \\
\hline $\mathrm{SC}$ & 142 & 677 & $\mathrm{BG}$ & 1996 & 2004 & $<0.25$ & 0.008 & 4.28 & UP \\
\hline $\mathrm{SC}$ & 182 & 1,408 & LMB & 1996 & 2004 & 0.37 & 0.186 & -1.46 & NONE \\
\hline $\mathrm{SC}$ & 68 & 186 & $\mathrm{CCF}$ & 1996 & 2004 & $<0.25$ & 0.100 & -3.88 & NONE \\
\hline \multicolumn{10}{|c|}{ Midwestern USA } \\
\hline IA & 37 & 46 & $\mathrm{CC}$ & 1996 & 2005 & 0.09 & 0.445 & -2.48 & NONE \\
\hline IA & 44 & 57 & $\mathrm{CCF}$ & 1996 & 2005 & 0.06 & 0.384 & -4.31 & NONE \\
\hline IN & 158 & 185 & $\mathrm{CC}$ & 1996 & 2004 & 0.16 & $<0.001$ & 8.87 & UP \\
\hline IN & 39 & 45 & $\mathrm{CCF}$ & 1997 & 2004 & 0.13 & 0.302 & 3.19 & NONE \\
\hline IN & 71 & 84 & LMB & 1996 & 2004 & 0.18 & 0.980 & -0.06 & NONE \\
\hline $\mathrm{MN}$ & 45 & 110 & $\mathrm{CC}$ & 1996 & 2001 & 0.13 & 0.285 & 3.19 & NONE \\
\hline $\mathrm{MN}$ & 44 & 115 & W & 1996 & 2001 & 0.20 & 0.088 & 6.98 & NONE \\
\hline$M N$ & 33 & 82 & $N P$ & 1996 & 2001 & 0.24 & 0.002 & -12.8 & DOWN \\
\hline
\end{tabular}

Significant trends $(p$ value $<0.05)$ are shaded. Trends above EPA advisory guideline $(0.3 \mu \mathrm{g} / \mathrm{g} \mathrm{MeHg})$ are in bold text. Upward trends starting below and ending above EPA guideline are underlined. Downward trends starting above and ending below EPA guideline are in italics. Trends below EPA guideline are in regular text

$B M B U$ bigmouth buffalo, $B C$ black crappie, $B C F$ blue catfish, $B G$ bluegill, $B$ bowfin, $C C F$ channel catfish , $C C$ common carp, $F C F$ flathead catfish, $F D$ freshwater drum, $L M B$ largemouth bass, $N P$ northern pike, $R S$ redear sunfish, $W$ walleye, $W C$ white crappie 
tersheds should promote transformation of inorganic $\mathrm{Hg}$ to $\mathrm{MeHg}$. In addition, the smaller South Carolina watersheds would be expected to respond more rapidly to changes in $\mathrm{Hg}$ emissions (Grigal 2002). To minimize potential problems resulting from differences in site types, collection protocols, and analytical procedures between the NCBP and the ScDHEC, site-specific trends focused on a subset of 50 NCBP sites sampled from 1969 to 1987 (Table 2) before ScDHEC implemented a monitoring program.

Statewide data were used for the evaluation of trends from 1988 to 2005 . The statewide datasets were composed of 14 fish species and two tissue types (skin-on and skin-off fillets). Of the fish species collected, $73 \%$ were from the upper trophic level (Table 1). Data for eight states (four midwest and four southeast, Table 3) met the 1988-2005 criteria. The midwestern states implemented their sampling programs earlier than the southeastern states. The average length of record for the eight states was 12 years. Only
Iowa had data that spanned the full period from 1988 to 2005. Statewide trends in fish $\mathrm{Hg}$ were analyzed from 1996 to 2005 for comparison with wet $\mathrm{Hg}$ deposition during the same period. Data for six states (three midwest and three southeast, Table 4) met the 1996-2005 criteria.

\section{Results}

Site trends, 1969-2005

$\mathrm{Hg}$ concentrations in fish between 1969 and 2005 from 90 river and lake sites across the USA had no temporal trends at $57 \%$ of the sites, downwards trends at $32 \%$ of the sites, and upward trends at $11 \%$ of the sites (Fig. 1; Supplemental Table A). The direction of trends was similar at river and lake or impounded sites. Fifty percent of the lake and impounded sites and $41 \%$ of the river sites had trends, the ratio of downward to upward trends being 9 to 2 for lakes and impoundments

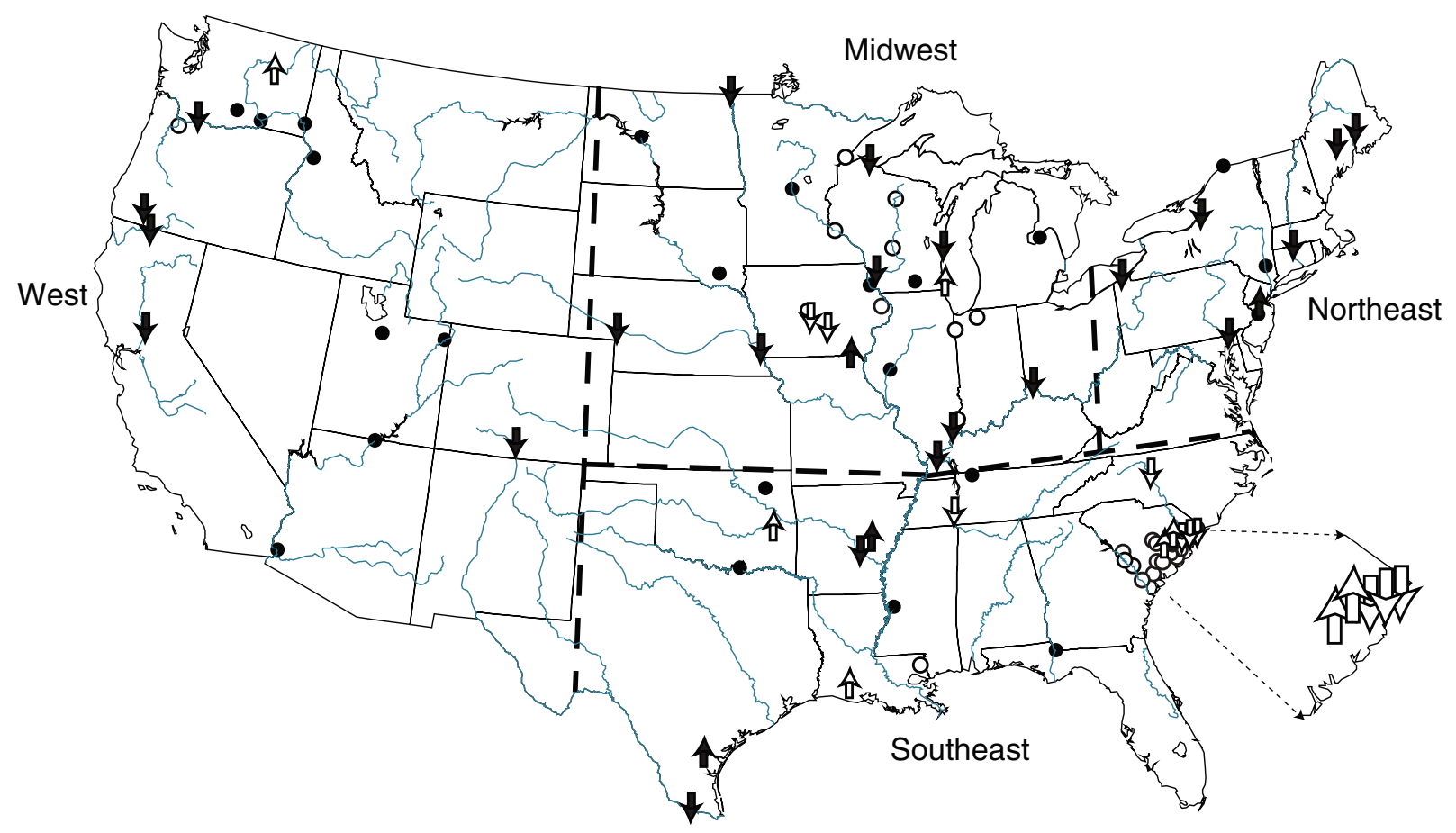

Fig. 1 Map showing $\mathrm{Hg}$ trends in fish tissue at 90 sites in the USA, 1969-2005. One site in Alaska (no trend) is not shown. Arrows sites with significant trends $(p<0.05)$. Circles sites without significant trends. Black symbols 50 sites sampled 1969-1987. White symbols 40 sites sampled mostly 1988-2005. Trends in South Carolina are shown in larger view. Heavy dashed lines mark four regions of the country 
and 5 to 2 for rivers. The trophic level of fish species, as defined by their food habits, did not appear to affect $\mathrm{Hg}$ trends. Downward trends were found in $26 \%$ of fish species in the lower trophic level and in $28 \%$ of fish in the upper trophic level. Twice as many downward trends as upward trends were found in fish species from both lower and upper trophic levels. The overall ratio of downward and upward trends in fish $\mathrm{Hg}$ concentrations were relatively even at sites across most of the country: the ratio of downward to upward trends was about 6 to 1 except in the southeast, where it was 4 to 3 (Fig. 2).

Twelve of the 39 sites with temporal $\mathrm{Hg}$ trends in fish had $\mathrm{Hg}$ concentrations in fish tissue greater than $0.3 \mu \mathrm{g} / \mathrm{g}$, the EPA advisory level for protection of human health (Supplemental Table A). Of the 12 sites, six sites in the northern USA had fish $\mathrm{Hg}$ concentrations starting above EPA guidelines and ending below the guidelines, three sites in the southeastern USA had fish $\mathrm{Hg}$ concentrations starting below EPA guidelines and ending above EPA guidelines, and three sites in South Carolina with downward trends had fish $\mathrm{Hg}$ concentrations that remained above EPA guidelines.

Site trends, 1969-1987

Site trends were focused on a subset of 50 NCBP sites from 1969 to 1987 (Fig. 1; Table 2). These trends in $\mathrm{Hg}$ concentrations in fish were down- ward for 22 sites, upward for four sites, and no trends for 24 sites. More downward $\mathrm{Hg}$ trends were found at sites in the northeast, midwest, and west than at sites in the southeast (Fig. 2). Thirteen of the 22 sites with downward trends had an inflection point around 1980, from an initial rapid decrease in fish $\mathrm{Hg}$ concentrations in the 1970s to a more gradual decrease, or to no decrease in fish $\mathrm{Hg}$ concentration in the 1980s (Fig. 3). May and McKinney (1981), Lowe et al. (1985), Schmitt and Brumbaugh (1990), and Schmitt et al. (1999) reported similar changes in fish $\mathrm{Hg}$ concentrations from NCBP data. May and McKinney (1981) found the only significant decrease in national geometric mean fish $\mathrm{Hg}$ concentrations in the NCBP data was from 1972 to 1977 . No significant changes in national geometric mean $\mathrm{Hg}$ concentration were found in the NCBP data from 1978 to 1981 (Lowe et al. 1985) or from 1976 to 1984 (Schmitt and Brumbaugh 1990).

Statewide trends, 1988-2005

Fish data, aggregated by state and by species, were used for evaluation of trends in fish $\mathrm{Hg}$ concentrations from 1988 to 2005 (Table 3). No trends in fish $\mathrm{Hg}$ concentrations were found in $52 \%$ of fish species from eight states. The only upward statewide trends in fish $\mathrm{Hg}$ concentrations were found in southeastern states (Supplemental Fig. A). Upward statewide trends in $\mathrm{Hg}$ concentrations
Fig. 2 Direction and magnitude of significant trends $(p$ value $<0.05)$ in $\mathrm{Hg}$ concentration in fish tissue between 1969 and 2005. Black bars trends at 26 sites sampled 1969-1987. White bars trends at 13 sites sampled mostly 1988-2005

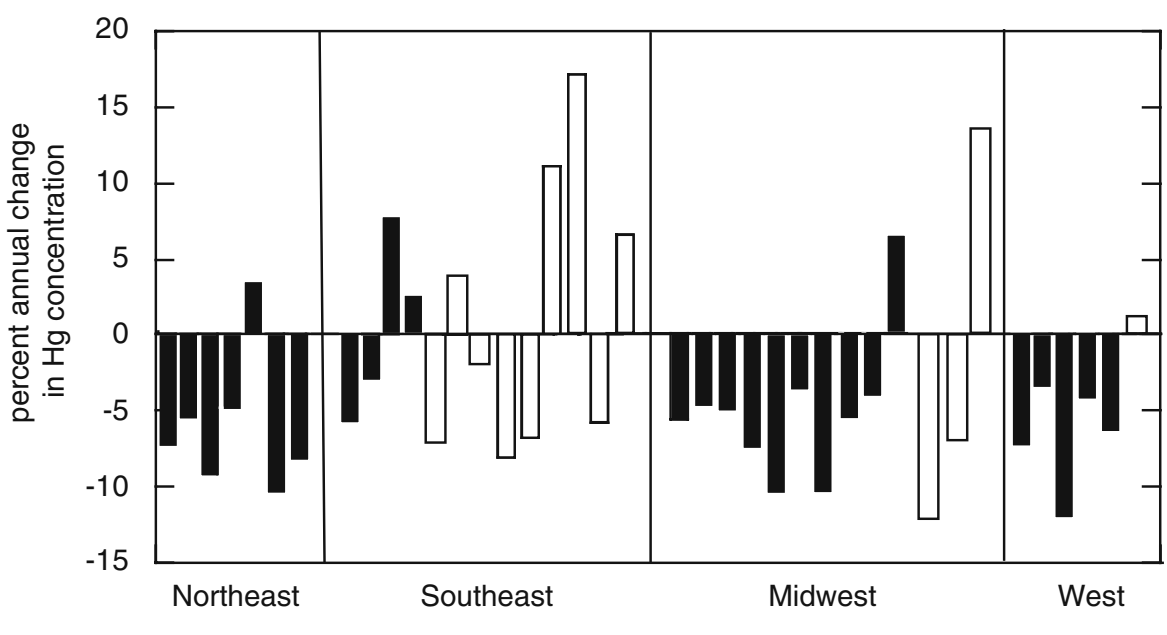

U.S. region 


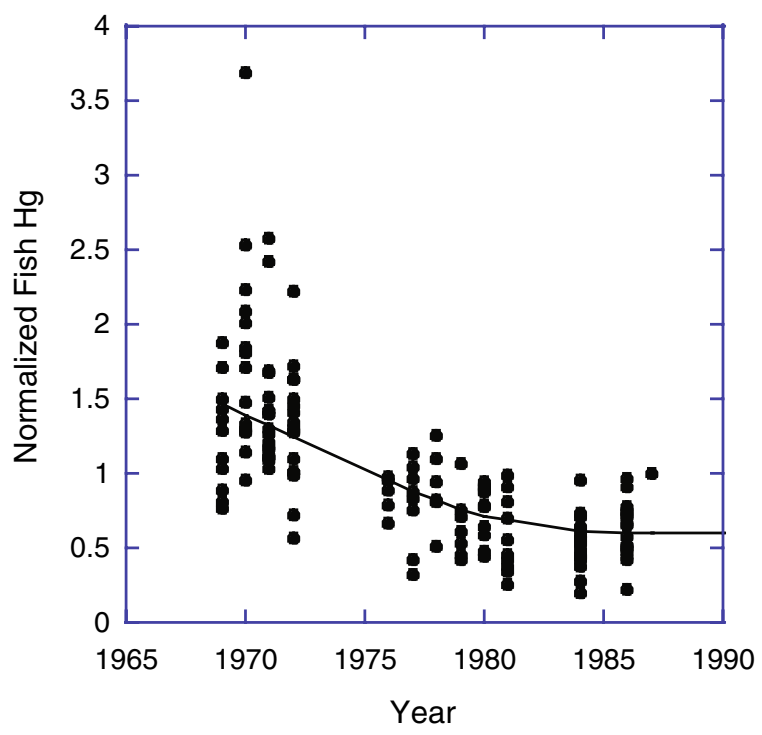

Fig. 3 Normalized $\mathrm{Hg}$ concentrations in whole fish collected by the National Contaminant Biomonitoring Program from 22 sites with significant $(p<0.05)$ downward trends, 1969-1987. Fish Hg concentrations were normalized by expressing the $\mathrm{Hg}$ concentrations of each fish as a percentage of the mean $\mathrm{Hg}$ concentration for that fish species and site. The curve is fitted using the locally weighted least squared error method. Trend analysis results for these sites are in Table 2

in fish were detected in Louisiana largemouth bass, channel catfish (Ictalurus punctatus), and freshwater drum (Aplodinotus grunniens); in South Carolina bowfin ( $A$. calva); and in Georgia largemouth bass. Upward trends were above EPA advisory level for protection of human health guidelines in South Carolina bowfin. Upward trends in Louisiana largemouth bass and freshwater drum and Georgia largemouth bass started below EPA guidelines in the early 1990s and ended above the guidelines in the early to mid-2000s. Downward trends were detected in Louisiana bowfin and bigmouth buffalo (Ictiobus cyrinellus) and in South Carolina largemouth bass. Downward trends in Louisiana bowfin and South Carolina largemouth bass remained above the EPA advisory level into the mid-2000s (Supplemental Fig. A). States in the midwest had fewer trends than states in the southeast. No trends were detected in eight out of 12 fish species from states in the midwest (Table 3). All the statewide trends in fish $\mathrm{Hg}$ concentrations were downward in midwestern states (Table 3). Downward trends were detected in Iowa common carp (C. carpio) and channel catfish and in Minnesota northern pike (Esox lucius) and walleye (Sander vitreus) (Supplemental Fig. A). Downward $\mathrm{Hg}$ trends in Iowa common carp and channel catfish were below EPA guidelines from the late 1980s and early 1990s to 2005. Downward trends in Minnesota northern pike and walleye started at or above EPA guidelines in the late 1980s and fell below the guidelines by 2001 . Downward trends in midwestern states have been observed in other studies. Downward trends in walleye from northern Wisconsin lakes were also reported by Madsen and Stern (2007) between 1982 and 2005. Rasmussen et al. (2007) found trends between 1982 and 2005 in Wisconsin walleye varied with latitude; northern lakes had downward trends, middle latitude had no trends, and southern lakes had upward trends.

Some of the differences in fish $\mathrm{Hg}$ trends between states in the midwest and states in the southeast may reflect the period in which the samples were collected. Data from most states did not span the entire period from 1988 to 2005 . In the midwest, most of the samples were collected during the late 1980s and 1990s, whereas most of the samples in the southeast were collected during the late 1990s and early 2000s. Monson (2009) reported downward trends for $\mathrm{Hg}$ concentrations in northern pike and walleye fromMinnesota lakes before the mid-1990s, followed by upward trends after the mid-1990s.

Statewide trends, 1996-2005

Fish $\mathrm{Hg}$ data, aggregated by state and by species, were also evaluated from 1996 to 2005 for comparison with wet $\mathrm{Hg}$ deposition during the same period (Table 4). No $\mathrm{Hg}$ trends were found in $62 \%$ of fish species from six states. Fish $\mathrm{Hg}$ trends from states in the southeast were mostly upward. Upward trends were found in four South Carolina fish species [bowfin, blue catfish (I. furcatus), redear sunfish (Lepomis microlophus), and bluegill (Lepomis macrochirus)]. In Louisiana, upward trends in $\mathrm{Hg}$ concentrations were found in three species [flathead catfish (Pylodictis olivaris), channel catfish, and largemouth bass], and a downward 
trend in one species (bowfin). Trends in $\mathrm{Hg}$ concentrations in the midwest were mixed; upward trends in Indiana channel catfish and downward trends in Minnesota northern pike (Table 4).

\section{Discussion}

\section{Comparison to atmospheric emissions}

An important question is whether trends in fish $\mathrm{Hg}$ concentration mirror trends in $\mathrm{Hg}$ emissions or trends in $\mathrm{Hg}$ inputs to aquatic ecosystems, or both. Major sources of anthropogenic $\mathrm{Hg}$ include mining, emissions from fossil fuel combustion, industrial processes (metal smelting and refining, chemical production, cement, and pulp and paper), and waste incineration (USEPA 1997). From about 1940 to 1970, a period of rapid industrial growth and inadequate wastewater treatment, local point-sources were the dominant source of $\mathrm{Hg}$ in many urbanized areas (Pirrone et al. 1998; Balogh et al. 1999). Improved wastewater treatment, stricter regulation of discharges to air and surface waters (USEPA Clean Water Act, Clean Air Act, Safe Drinking Water Act, and Toxic Substance Control Act), and reductions in industrial use of $\mathrm{Hg}$ since the 1960s have eliminated most $\mathrm{Hg}$ point-sources in urban areas (Balogh et al. 1999). The rapid decrease in $\mathrm{Hg}$ concentrations in fish collected by the NCBP in the 1970s likely results from this overall reduction of $\mathrm{Hg}$ in direct releases to the atmosphere and surface waters (Fig. 3; May and McKinney 1981; Krabbenhoft et al. 2005). Regulations since 1990 have targeted air emissions (Clean Air Amendments; USEPA 2004; USEPA 2007). Estimated anthropogenic $\mathrm{Hg}$ emissions from the USA have decreased by almost $50 \%$ in the northeast and over $30 \%$ in the southeast and midwest between the mid-1990s and 2002 (Supplemental Fig. B). Over a similar period from the mid-1980s through the early 2000s, the BEST program reported that temporal trends in fish $\mathrm{Hg}$ concentrations were not evident in nine major river basins (Mississippi, Columbia, Rio Grande, Yukon, Colorado, Mobile, Apalachicola, Savannah, and PeeDee; Schmitt 2002; Hinck et al. 2006a; Schmitt et al. 2005; Hinck et al. 2007; Hinck et al. 2006b;
Hinck et al. 2004). We also found few downward trends in $\mathrm{Hg}$ concentrations in fish during this period (Tables 3 and 4).

Several factors could eliminate or delay any response in fish $\mathrm{Hg}$ concentrations to changes in anthropogenic $\mathrm{Hg}$ emissions. About half of the anthropogenic emissions contributing to $\mathrm{Hg}$ deposition in the USA originate from other countries (Seigneur et al. 2004). Although US emissions are decreasing, emissions from Asia and Africa are increasing (Pacyna et al. 2006), with the result that the global anthropogenic emission inventory has remained almost constant since the 1990s (Slemr et al. 2003). Estimated global anthropogenic emissions were between 1,270 and 2,140 tons per year in 1990, 1,900 tons per year in 1995 (Pacyna and Pacyna 2002), and 2,200 tons per year in 2000 (Pacyna et al. 2006). A lag between actual reductions in anthropogenic $\mathrm{Hg}$ emissions and decreases in atmospheric $\mathrm{Hg}$ occurs because re-emitted, natural, and anthropogenic emission sources each contribute roughly equal amounts of $\mathrm{Hg}$ to the atmosphere (Seigneur et al. 2004). Thus, measures of $\mathrm{Hg}$ deposition are better indicators of $\mathrm{Hg}$ loading than anthropogenic emissions.

\section{Comparison to sediment cores}

Although few records of atmospheric $\mathrm{Hg}$ deposition exist before 1995 (http://nadp.sws.uiuc. edu/mdn/), $\mathrm{Hg}$ deposition back to pre-industrial times can be estimated from sediment, peat, and ice cores (Schuster et al. 2002). Dated depth profiles of $\mathrm{Hg}$ in sediment cores show changes in $\mathrm{Hg}$ accumulation rates over time that correlate well with documented $\mathrm{Hg}$ utilization and environmental releases and have been shown to be an accurate record of changes in external loading (Krabbenhoft et al. 2007; Lockhart et al. 2000; Lamborg et al. 2002; Pirrone et al. 1998; Engstrom and Swain 1997). Declining $\mathrm{Hg}$ accumulation rates in lake sediments and bog peat have been reported for many areas of the USA from 1970 through 1990 (Norton et al. 1997; Engstrom and Swain 1997; Balogh et al. 1999; Lorey and Driscoll 1999; Kamman and Engstrom 2002; Van Metre et al. 2004; Perry et al. 2005; Mahler et al. 2006). These declining $\mathrm{Hg}$ accumulation rates have been at least partially attributed to improved wastewa- 
ter treatment, stricter regulatory controls on discharges to air and surface waters, and reductions in industrial use of $\mathrm{Hg}$ during the 1960s and 1970s.

Fish $\mathrm{Hg}$ trends corresponded with the declining $\mathrm{Hg}$ accumulation rates found in many sediment cores and the implementation of stricter regulatory controls on direct releases to the atmosphere and surface waters in the 1970s. Most downward trends in fish $\mathrm{Hg}$ occurred between 1969 and 1987 (Fig. 2), with the most rapid decreases in $\mathrm{Hg}$ concentrations during the 1970s (Fig. 3). In particular, the direction of fish $\mathrm{Hg}$ trends at the 50 NCBP sites from 1969 to 1987 was similar to that in trends found in the USGS National Water Quality Assessment program sediment cores from 35 lake and reservoir sites characterizing $\mathrm{Hg}$ from 1970 to 2001 (Mahler et al. 2006). No trends in $\mathrm{Hg}$ concentrations were found in about half of the sediment core and fish tissue sites. In addition, there were more downward $\mathrm{Hg}$ trends in sediment cores and fish (35\% and $44 \%$, respectively) than upward trends (17\% and $8 \%$, respectively).

\section{Comparison to wet deposition}

$\mathrm{Hg}$ deposition occurs in two forms: wet deposition (associated with precipitation) and dry deposition (direct deposition of gaseous $\mathrm{Hg}(0)$ and $\mathrm{Hg}(\mathrm{II})$, and deposition of particles containing $\mathrm{Hg}$; Lindberg et al. 2007). Many studies have demonstrated that dry deposition processes may contribute amounts of mercury to the landscape equal to or greater than wet deposition (Miller et al. 2005; Seigneur et al. 2004; Grigal 2002; Cohen et al. 2004; Driscoll et al. 2007) however, insufficient dry deposition data are available at this time to quantify trends. Wet deposition of atmospheric $\mathrm{Hg}$ in the USA has been measured by the Mercury Deposition Network since the mid-1990s. Forty-nine MDN sites were tested for trends using a Seasonal Kendall approach (Prestbo and Gay 2009). These were primarily rural sites in the eastern USA and Canada. No trends in annual $\mathrm{Hg}$ wet deposition rate were found in $76 \%$ of the sites (Prestbo and Gay 2009). Downward trends in wet $\mathrm{Hg}$ deposition were found at $18 \%$ of the sites and upward trends were found in $6 \%$ of the sites. Trends in wet $\mathrm{Hg}$ deposition were complicated by trends in amounts of precipitation. Of the nine sites with downward trends in wet $\mathrm{Hg}$ deposition, three sites also had decreasing amounts of precipitation that could account for the decrease in wet deposition. Similarly, two of the three sites (in Louisiana) with upward trends in wet deposition also had increasing amounts of precipitation, possibly explaining the increase in wet deposition over that period. The use of volume-weighted concentrations avoids the effect of variations in precipitation on deposition, but is less relevant when comparing to fish. What affects $\mathrm{Hg}$ concentrations in fish is not so much the concentration of $\mathrm{Hg}$ in wet deposition, but the amount of $\mathrm{Hg}$ entering the ecosystem, in other words, deposition.

Site-specific and statewide trend analyses consistently showed more upward trends in $\mathrm{Hg}$ concentrations in fish in southeastern states than other regions of the country (Figs. 1 and 2; Tables 3 and 4; Supplemental Table A). More upward $\mathrm{Hg}$ trends in fish in the southeast corresponded with the increased wet deposition in the region. Louisiana was the only state in which upward trends in $\mathrm{Hg}$ wet deposition were found (Fig. 4). Butler et al. (2008) also reported an upward trend in $\mathrm{Hg}$ wet deposition in the southeastern USA from 1998 to 2005, however, the upward trend was at a MDN site in Florida not Louisiana. The southeastern states may be more heavily influenced by long-range global transport resulting from large convective summer storms that scavenge $\mathrm{Hg}$ from the middle and upper troposphere (Butler et al. 2008). Increasing Asian Hg emissions may therefore have a greater impact in the southeastern USA than elsewhere in North America.

Fewer $\mathrm{Hg}$ trends in fish and wet deposition from 1996 to 2005 were found in the midwest than in the southeast. Only one downward trend in $\mathrm{Hg}$ wet deposition was detected among $14 \mathrm{MDN}$ sites in the midwest (Fig. 4). Of eight midwest fish species analyzed for statewide $\mathrm{Hg}$ trends from 1996 to 2005, only two trends were detected: one upward (channel catfish in Indiana) and one downward (northern pike in Minnesota; Table 4). Butler et al. (2008) also reported downward $\mathrm{Hg}$ trends in wet deposition at two sites in Minnesota.

Although there were insufficient fish data from the northeastern USA for statewide trend analy- 
Fig. 4 Comparison of $\mathrm{Hg}$ trends in channel catfish fillets to $\mathrm{Hg}$ trends in wet deposition at Mercury Deposition Network sites in the eastern USA and Canada, 1996-2005.

Trends in channel catfish were analyzed in five states: Iowa, Illinois, Louisiana, South Carolina, and Georgia. Grey states upward trends in channel catfish fillets. Black states no trends in channel catfish fillets. Arrows direction of wet deposition trends at MDN sites. Circles MDN sites without wet deposition trends. Dashed lines mark regions of the USA

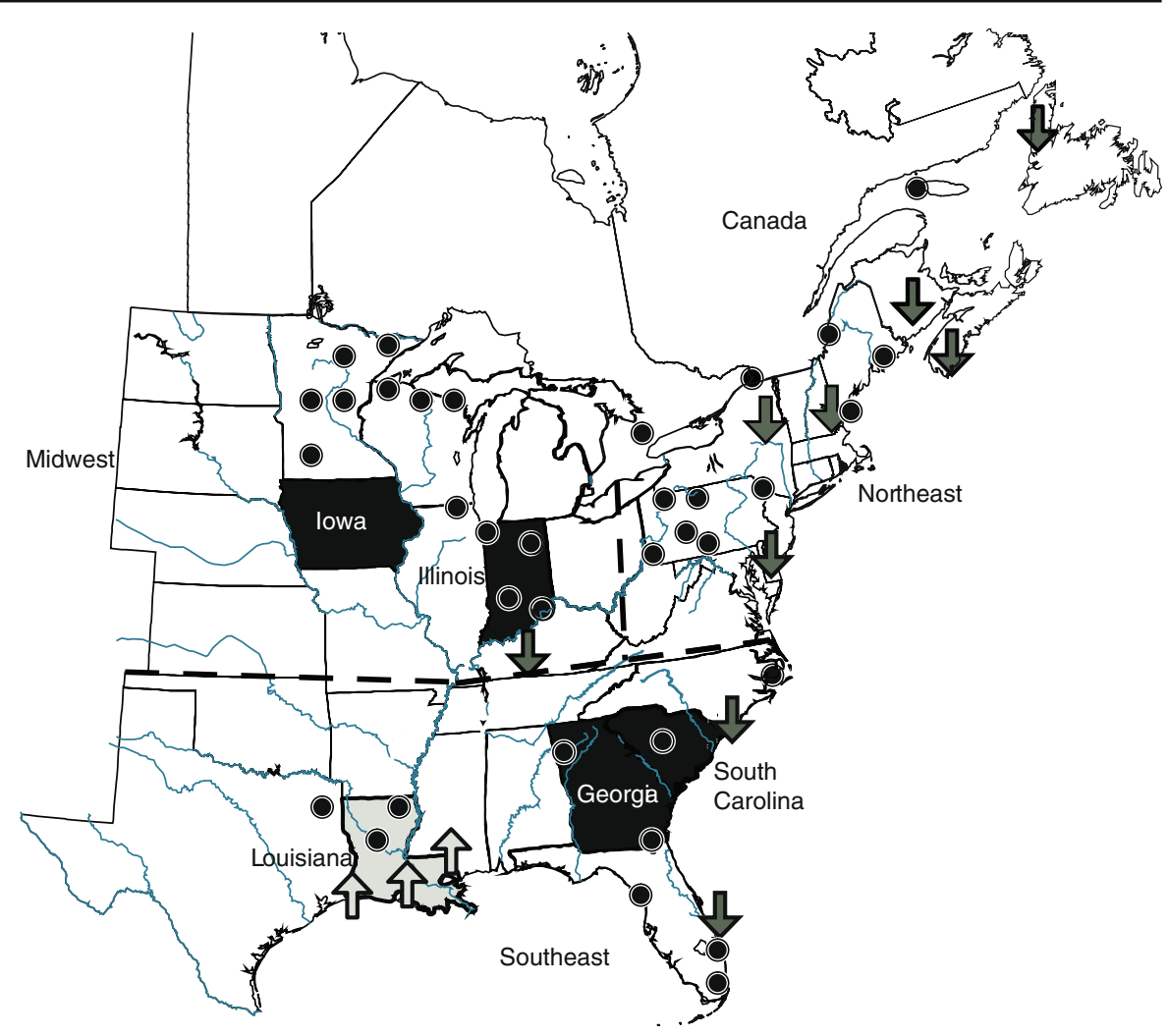

ses, site-specific data (1969-1987) indicate downward trends at six out of 10 sites in the northeastern USA (Fig. 1; Table 2). More recently, Simonin et al. (2009) reported an average decrease of $14 \%$ in $\mathrm{Hg}$ concentrations in yellow perch from lakes in New York from 1987 to 2005. These results correspond with those for MDN sites in the northeast, including Nova Scotia and Newfoundland, where downward trends in $\mathrm{Hg}$ wet deposition were found at six out of 15 sites (Fig. 4). In contrast, Butler et al. (2008) reported no trends in $\mathrm{Hg}$ wet deposition at $12 \mathrm{MDN}$ sites in the northeast from 1998 to 2005. Overall, no trends were found in $62 \%$ of statewide fish $\mathrm{Hg}$ data and in $80 \%$ of MDN wet deposition sites in the eastern USA from 1996 to 2005 (Table 4; Fig. 4). By comparison, Butler et al. (2008) reported no trends in wet deposition at $88 \%$ of MDN sites in the eastern USA from 1998 to 2005. Differences between $\mathrm{Hg}$ wet deposition trends reported by Prestbo and Gay (2009) and Butler et al. (2008) most likely were due to the different ways of data aggregation (weekly data, versus annual and warm season, respectively), and lengths of record (1996-2005 versus 1998-2005, respectively).

Response time

Although few $\mathrm{Hg}$ trends were detected in either fish tissue or atmospheric wet deposition from 1996 to 2005 in the eastern USA, it is anticipated that $\mathrm{Hg}$ concentrations in fish will respond to changes in atmospheric $\mathrm{Hg}$ loading. Recent studies have linked levels of atmospheric $\mathrm{Hg}$ loading with $\mathrm{Hg}$ concentrations in fish (Hrabik and Watras 2002; Atkeson et al. 2003; Hammerschmidt and Fitzgerald 2006), loons (Evers et al. 2007), and mosquitoes (Hammerschmidt and Fitzgerald 2005), and directly with $\mathrm{MeHg}$ production (Orihel et al. 2006; Hammerschmidt et al. 2006). Hammerschmidt and Fitzgerald (2006) reported that $\mathrm{Hg}$ wet deposition between 1992 and 2004 accounted for about two-thirds of $\mathrm{Hg}$ variation in largemouth bass between 1990 and 1995. Hammerschmidt 
and Fitzgerald (2006) suggested that reductions in anthropogenic $\mathrm{Hg}$ emissions could result in proportionally lower levels of $\mathrm{Hg}$ concentrations in fish, but that the magnitude and timing of the response are unclear. The response to reductions in $\mathrm{Hg}$ emissions near sources (mostly inorganic $\mathrm{Hg}$ ) is expected to be more rapid than at remote locations dominated by input from the global $\mathrm{Hg}$ pool (mostly elemental Hg; Lindberg et al. 2007). Slower response times are expected in systems with large watershed to water surface ratios due to retention of $\mathrm{Hg}$ in the watershed (Grigal 2002). The storage of previously deposited $\mathrm{Hg}$ within the watershed coupled with gradual delivery downstream can create a time lag between implementation of $\mathrm{Hg}$ emission controls and reductions in $\mathrm{Hg}$ accumulation in lake sediments and aquatic biota (Kamman and Engstrom 2002). Therefore, the watershed could remain a major source of $\mathrm{Hg}$ to lakes and rivers for many years and delay the response of aquatic ecosystems to changes in emissions (Yang et al. 2002). However, recent $\mathrm{Hg}$ emissions appear to be more readily methylated, suggesting at least an initial rapid decrease in fish $\mathrm{Hg}$ concentration after reductions in $\mathrm{Hg}$ emissions (Harris et al. 2007; Hintelmann et al. 2002). As a result of these complexities and uncertainties, $\mathrm{Hg}$ concentrations in fish could respond over months, years, or decades following changes in atmospheric $\mathrm{Hg}$ emissions. If the reduction in $\mathrm{Hg}$ emissions is relatively small compared to the inventories of $\mathrm{Hg}$ in the ecosystem, the response of fish $\mathrm{Hg}$ concentrations is expected to occur more slowly and be smaller in magnitude (Krabbenhoft et al. 2007).

\section{Conclusions}

A national compilation of fish $\mathrm{Hg}$ data from state and federal monitoring programs was used to analyze trends in $\mathrm{Hg}$ concentrations in fish. Most downward trends in fish $\mathrm{Hg}$ occurred between 1969 and 1987, with the most rapid decreases in $\mathrm{Hg}$ concentrations during the 1970s. Fish $\mathrm{Hg}$ trends corresponded with the declining $\mathrm{Hg}$ accumulation rates found in many sediment cores and the implementation of stricter regulatory controls on direct releases to the atmosphere and surface waters in the 1970s. The southeastern USA had more upward $\mathrm{Hg}$ trends in fish than other regions for both site and state aggregated data. Upward $\mathrm{Hg}$ trends in fish from the southeastern USA were associated with increases in wet deposition in the region. The southeastern states may be more heavily influenced by long-range global transport and increases in distant $\mathrm{Hg}$ emissions. No $\mathrm{Hg}$ trends were found in $62 \%$ of fish data, and $76 \%$ of wet deposition sites from 1996 to 2005 . Although few trends were detected in $\mathrm{Hg}$ data in fish or wet atmospheric deposition from 1996 to 2005, it is anticipated that $\mathrm{Hg}$ concentrations in fish will decrease in response to decreases in atmospheric $\mathrm{Hg}$ loading; however, the magnitude and the timing of the response are uncertain.

Acknowledgements This project was supported by the US Geological Survey National Water Quality Assessment program. We thank Barb Scudder and Cory Stevens for initiating the study and Stephen Wente for his extensive work on the EMMMA dataset. The manuscript was improved by suggestions from Jamie Shanley, Gregory Wetherbee, and Barbara Mahler of the US Geological Survey, and two anonymous reviewers.

Open Access This article is distributed under the terms of the Creative Commons Attribution Noncommercial License which permits any noncommercial use, distribution, and reproduction in any medium, provided the original author(s) and source are credited.

\section{References}

Allison, P. D. (1995). Survival analysis using SAS: A practical guide. Cary: SAS Institute Inc.

Atkeson, T., Axelrad, D., Pollman, C., \& Keeler, G. (2003). Integrating atmospheric mercury deposition and aquatic cycling in the Florida Everglades: An approach for conducting a total maximum daily load analysis for an atmospherically derived pollutant. Tallahassee, FL: Florida Department of Environmental Protection. http://www.floridadep.org/ labs/mercury/index.htm. Accessed 15 March 2009.

Balogh, S. J., Engstrom, D. R., Almendinger, J. E., Meyer, M. L., \& Johnson, D. K. (1999). History of mercury loading in the upper Mississippi River reconstructed from sediments of Lake Pepin. Environmental Science Technology, 33, 3297-3302.

Bloom, N. S. (1992). On the chemical form of mercury in edible fish and marine invertebrate tissue. Canadian Journal of Fisheries and Aquatic Sciences, 49, 10101017. 
Butler, T. J., Cohen, M. D., Vermeylen, F. M., Likens, G. E., Schmeltz, D., \& Artz, R. S. (2008). Regional precipitation mercury trends in the eastern USA, 1998-2005: Declines in the northeast and midwest, no trend in the southeast. Atmospheric Environment, 42, 1582-1592.

Chen, C. Y., \& Folt, C. L. (2005). High plankton densities reduce mercury biomagnification. Environmental Science and Technology, 39, 115-121.

Cohen, M., Artz, R., Draxler, R., Miller, P., Poissant, L., Niemi, D., et al. (2004). Modeling the atmospheric transport and deposition of mercury to the Great lakes. Environmental Research, 95, 247-265.

Downs, S. G., Macleod, C. L., \& Lester, J. N. (1998). Mercury in precipitation and its relation to bioaccumulation in fish: A literature review. Water, Air, and Soil Pollution, 108, 149-187.

Driscoll, C. T., Han, Y. J., Chen, C. Y., Evers, D. C., Lambert, K. F., Holsen, T. M., et al. (2007). Mercury contamination in forest and freshwater ecosystems in the northeastern United States. Bioscience, 57, 1728.

Engstrom, D. R., \& Swain, E. B. (1997). Recent declines in atmospheric mercury deposition in the upper midwest. Environmental Science and Technology, 31, 960967.

Evers, D. C., Han, Y., Driscoll, C. T., Kamman, N. C., Goodale, K., Lambert, F., et al. (2007). Biological mercury hotspots in the northeastern United States and southeastern Canada. BioScience, 57, 29-43.

Fitzgerald, W. F., Engstrom, D. R., Mason, R. P., \& Nater, E. A. (1998). The case for atmospheric mercury contamination in remote areas. Environmental Science and Technology, 32, 1-7.

Grigal, D. F. (2002). Inputs and outputs of mercury from terrestrial watersheds: A review. Environmental Review, 10, 1-39.

Hammerschmidt, C. R., \& Fitzgerald, W. F. (2005). Methylmercury in mosquitoes related to atmospheric mercury deposition and contamination. Environmental Science and Technology, 39, 3034-3039.

Hammerschmidt, C. R., \& Fitzgerald, W. F. (2006). Methylmercury in freshwater fish linked to atmospheric deposition. Environmental Science and Technology, 40, 7764-7770.

Hammerschmidt, C. R., Fitzgerald, W. F., Lamborg, C. H., Balcom, P. H., \& Tseng, C. M. (2006). Biogeochemical cycling of methylmercury in lakes and tundra watersheds of arctic Alaska. Environmental Science and Technology, 40, 1204-1211.

Harris, R. C., Rudd, J. W. M., Amyot, M., Babiarz, C. L., Beaty, K. G., Blanchfield, P. J., et al. (2007). Wholeecosystem study shows rapid fish-mercury response to changes in mercury deposition. www.pnas.org/ cgi/doi/10.1073/pnas.0704186104. Accessed 23 March 2009.

Helsel, D. R., \& Hirsch, R. M. (1992). Statistical methods in water resources. Amsterdam: Elsevier.

Hinck, J. E., Bartish, T. M., Blazer, V. S., Denslow, N. D., Gross, T. S., \& Myers, M. S. (2004). Biomonitoring of Environmental Status and Trends (BEST) pro- gram: Environmental contaminants and their effects on fish in the Yukon River Basin. U.S. Geological Survey Scientific Investigations Report 20045285. http://pubs.er.usgs.gov/usgspubs/sir/sir20045285. Accessed 15 March 2009.

Hinck, J. E., Schmitt, C. J., Blazer, V. S., Denslow, N. D., Bartish, T. M., Anderson, P. J., et al. (2006a). Environmental contaminants and biomarker responses in fish from the Columbia River and its tributaries: Spatial and temporal trends. Science of the Total Environment, 366, 549-578.

Hinck, J. E., Blazer, V. S., Denslow, N. D., Gross, T. S., Echols, K. R., Davis, A. P., et al. (2006b). Biomonitoring of Environmental Status and Trends (BEST) program: Environmental contaminants, health indicators, and reproductive biomarkers in fish from the Colorado River basin. U.S. Geological Survey Scientific Investigations Report 2006-5163. http://pubs.usgs.gov/sir/2006/5163/pdf/SIR06-5163.pdf. Accessed 15 March 2009.

Hinck, J. E., Blazer, V. S., Denslow, N. D., Echols, K. R., Gale, R. W., May, T. W., et al. (2007). Biomonitoring of Environmental Status and Trends (BEST) Program: Environmental contaminants, health indicators, and reproductive biomarkers in fish from the Mobile, Apalachicola-ChattahoocheeFlint, Savannah, and Pee Dee River basins. U.S. Geological Survey Scientific Investigations Report 20075176. http://pubs.usgs.gov/sir/2007/5176/. Accessed 15 March 2009.

Hintelmann, H., Harris, R., Heyes, A., Hurley, J. P., Kelly, C. A., Krabbenhoft, D. P., et al. (2002). Reactivity and mobility of new and old mercury deposition in a boreal forest ecosystem during the first year of the METAALICUS study. Environmental Science and Technology, 36, 5034-5040.

Hirsch, R. M., Alexander, R. B., \& Smith, R. A. (1991). Selection of methods for the detection and estimation of trends in water quality. Water Resources Research, 27(5), 803-813.

Hrabik, T. R. \& Watras, C. J. (2002). Recent declines in mercury concentration in a freshwater fishery: Isolating the effects of de-acidification and decreased atmospheric mercury deposition in Little Rock Lake. Science of the Total Environment, 297, 229-237.

Kamman, N. C., \& Engstrom, D. R. (2002). Historical and present fluxes of mercury to Vermont and New Hampshire lakes inferred from ${ }^{210} \mathrm{~Pb}$ dated sediment cores. Atmospheric Environment, 36, 1599-1609.

Krabbenhoft, D. P., Branfireum, B. A., \& Heyes, A. (2005). Biogeochemical cycles affecting the speciation, fate, and transport of mercury in the environment. In M. B. Parsens \& J. B. Perival (Eds.), Mercury: Sources, measurements, cycles, and effects, short course series (Vol. 34, pp. 139-156). Ottawa: Mineralogical Association of Canada.

Krabbenhoft, D. P., Engstrom, D., Gilmour, C., Harris, R., Hurley, J., \& Mason, R. (2007). Monitoring and evaluating trends in sediment and water indicators. In R. Harris, D. Krabbenhoft, R. Mason, M. W. Murray, 
R. Reash, \& T. Saltman (Eds.), Ecosystem responses to mercury contamination: Indicators of change (pp. 4787). New York: Society of Environmental Toxicology and Chemistry (SETAC) North America Workshop on Mercury Monitoring and Assessment, CRC.

Lamborg, C. H., Fitzgerald, W. F., Damman, A. W. H., Benoit, J. M., Balcom, P. H., \& Engstrom, D. R. (2002). Modern and historical atmospheric mercury fluxes in both hemispheres: Global and regional mercury cycling implications. Global Biogeochemical Cycles, 16(4), 1104. doi:10.1029/2001GB001847.

Lindberg, S., Bullock, R., Ebinghaus, R., Engstrom, D., Feng, X., Fitzgerald, W., et al. (2007). A synthesis of progress and uncertainties in attributing the sources of mercury in deposition. Ambio, 36(1), 19-32.

Lockhart, W. L., Macdonald, R. W., Outridge, P. M., Wilkinson, P., Delaronde, J. B., \& Rudd, J. W. M. (2000). Tests of the fidelity of lake sediment core records of mercury deposition to known histories of mercury contamination. Science of the Total Environment, 260, 171-180.

Lorey, P., \& Driscoll, C. T. (1999). Historical trends of mercury deposition in Adirondack Lakes. Environmental Science and Technology, 33, 718-722.

Lowe, T. P., May, T. W., Brumbaugh, W. G., \& Kane, D. A. (1985). National Contaminant Biomonitoring Program (NCBP): Concentrations of seven elements in freshwater fish, 1978-1981. Archives of Environmental Toxicology, 14, 363-388.

Madsen, E. R., \& Stern, H. S. (2007). Time trends of methylmercury in walleye in northern Wisconsin: A hierarchical bayesian analysis. Environmental Science and Technology, 41, 4568-4573.

Mahler, B. J., Van Metre, P. C., \& Callender, E. (2006). Trends in metals in urban and reference lake sediments across the United States, 1970-2001. Environmental Toxicology and Chemistry, 25(7), 1698-1709.

May, T. W., \& McKinney, G. L. (1981). Cadmium, lead, mercury, arsenic, and selenium concentrations in freshwater fish, 1976-77-National Pesticide Monitoring Program. Pesticides Monitoring Journal, 15(1), 14-38.

Miller, E. K., Van Arsdale, A., Keeler, G. J., Chalmers, A., Poissant, L., Kamman, N. C., et al. (2005). Estimation and mapping of wet and dry mercury deposition across northeastern North America. Ecotoxicology, 14, 53-70.

Monson, B. A. (2009). Trend reversal of mercury concentrations in piscivorous fish from Minnesota Lakes: 1982-2006. Environmental Science and Technology, $43,1750-1755$.

Norton, S. A., Evans, G. C., \& Kahl, J. S. (1997). Comparison of $\mathrm{Hg}$ and $\mathrm{Pb}$ fluxes to hummocks and hollows of ombrotrophic Big Heath Bog and to nearby Sargent Mt. Pond, Maine, USA. Water, Air, and Soil Pollution, 100, 271-286.

Orihel, D. M., Paterson, J. J., Gilmour, C. C., Bodaly, R. A., Blanchfield, P. J., Hintelmann, J., et al. (2006). Effect of loading rate on the fate of mercury in littoral mesocosms. Environmental Science and Technology, 40(19), 5992-6000.
Pacyna, E. G., \& Pacyna, J. M. (2002). Global emission of mercury from anthropogenic sources in 1995. Water, Air and Soil Pollution, 137, 149-165.

Pacyna, E. G., Pacyna, J. M., Steenhuisen, F., \& Wilson, S. (2006). Global anthropogenic mercury emission inventory for 2000. Atmospheric Environment, 40, 4048-4063.

Perry, E., Norton, S. A., Kamman, N. C., Lorey, P. M., \& Driscoll, C. T. (2005). Deconstruction of historical mercury accumulation in lake sediments, northeastern United States. Ecotoxicology, 14, 85-99.

Peterson, S. A., Sickle, J. V., Herlihy, A. T., \& Hughes, R. M. (2007). Mercury concentrations in fish from streams and rivers throughout the western United States. Environmental Science and Technology, 41, 58-65.

Pirrone, N., Allegrini, I., Keeler, G. J., Nriagu, J. O., Rossmann, R., \& Robbins, J. A. (1998). Historical atmospheric mercury emissions and depositions in North America compared to mercury accumulations in sedimentary records. Atmospheric Environment, 32(5), 929-940.

Prestbo, E. M., \& Gay, D. A. (2009). Wet deposition of mercury in the U.S. and Canada, 1996-2005: Results and analysis of the NADP Mercury Deposition Network (MDN). Atmospheric Environment, 43, 4223-4233.

Rasmussen, P. W., Schrank, C. S., \& Campfield, P. A. (2007). Temporal trends of mercury concentrations in Wisconsin walleye (Sander vitreus), 1982-2005. Ecotoxicology, 16, 541-550.

SAS Institute, Inc (2002). SAS/STAT user's guide (version 8.02). Cary: SAS Institute, Inc.

Schmitt, C. J. (2002). Biomonitoring of Environmental Status and Trends (BEST) program: Environmental contaminants and their effects on fish in the Mississippi River basin. U.S. Geological Survey Biological Science Report USGS/BRD/BSR 20020004. http://pubs.er.usgs.gov/usgspubs/bsr/bsr020004. Accessed 15 March 2009.

Schmitt, C. J., \& Brumbaugh, W. G. (1990). National Contaminant Biomonitoring Program (NCBP): Concentrations of arsenic, cadmium, copper, lead, mercury, selenium, and zinc in U.S. freshwater fish, 1976-1984. Archives of Environmental Contaminant Toxicology, 19, 731-747.

Schmitt, C. J., Zajicek, J. L., May, T. W., \& Cowman, D. F. (1999). Organochlorine residues and elemental contaminants in U.S. freshwater fish, 1976-1986: National Contaminant Biomonitoring Program. Reviews of Environmental Toxicology, 162, 43-104.

Schmitt, C. J., Hinck, J. E., Blazer, V. S., Denslow, N. D., Dethloff, G. M., Bartish, T. M., et al. (2005). Environmental contaminants and biomarker responses in fish from the Rio Grande and its U.S. tributaries: Spatial and temporal trends. Science of the Total Environment, 350, 161-193.

Schuster, P. F., Krabbenhoft, D. P., Naftz, D. L., Cecil, L. D., Olson, M. L., DeWild, J. F., et al. (2002). Atmospheric mercury deposition during the last 270 years: A glacial ice core record of natural and 
anthropogenic sources. Environmental Science and Technology, 36, 2303-2310.

Seigneur, C., Vijayaraghavan, K., Lohman, K., Karamchandani, P., \& Scott, C. (2004). Global source attribution for mercury deposition in the United States. Environmental Science and Technology, 38, $555-569$.

Slemr, F., Brunke, E., Ebinghaus, R., Temme, C., Munthe, J., Wangberg, I., et al. (2003). Worldwide trend of atmospheric mercury since 1977. Geophysical Research Letters, 30(10), 1516-1519. doi:10.1029/ 2003 GL016954.

Simonin, H. A., Loukmas, J. J., Skinner, L. C., Roy, K. M., \& Paul, E. A. (2009). Trends in mercury concentrations in New York fish. Bulletin of Environmental Contaminant Toxicology, 83, 214-218.

U.S. Environmental Protection Agency (USEPA) (2007). EPA Fact Sheet: 2005/2006 National listing of fish advisories. U.S. Environmental Protection Agency, Washington, DC, USA, EPA-823-F-07-003. http://www.epa.gov/waterscience/fish/advisories/2006/ tech.pdf. Accessed 16 April 2009.

USEPA (1997). Mercury Study Report to Congress. U.S. Environmental Protection Agency, Washington, D.C, USA, USEPA 452R-97-004.

USEPA (2004). http://www.epa.gov/mercury/control_ emissions/emissions.htm. Accessed 23 March 2009.

USEPA (2006). National Hydrography Dataset Plus. http://www.epa.gov/waters. Accessed 23 March 2009.

U. S. Geological Survey (2000). National Land Cover Data (NLCD) circa 1992, completed nationwide September 2000. http://seamless.usgs.gov/. Accessed 23 March 2009.
Van Metre, P. C., Wilson, J. T., Fuller, C. C., Callender, E., \& Mahler, B. J. (2004). Methods, site characteristics, and age dating of sediment cores for 56 U.S. lakes and reservoirs sampled by the USGS National Water-Quality Assessment program, 1993-2001. U.S. Geological Survey SIR 2004-5184.

Wiener, J. G., Krabbenhoft, D. P., Heinz, G. H., \& Scheuhammer, A. M. (2003). Ecotoxicology of mercury. In D. J. Hoffman, B. A. Rattner, G. A. Burton Jr., \& J. Cairns Jr. (Eds.), Handbook of ecotoxicology (2nd ed., pp. 409-463). Boca Raton: CRC Press.

Wiener, J. G., Knights, B. C., Sandheinrich, M. B., Jeremiason, J. D., Brigham, M. E., Engstrom, D. R., et al. (2006). Mercury in soils, lakes, and fish in Voyageurs National Park (Minnesota): Importance of atmospheric deposition and ecosystem factors. Environmental Science and Technology, 40, 6261-6268.

Wiener, J. G., Bodaly, R. A., Brown, S. S., Lucotte, M., Newman, M. C., Porcella, D. B., et al. (2007). Monitoring and evaluating trends in methylmercury accumulation in aquatic biota. In R. Harris, D. P. Krabbenhoft, R. Mason, M. W. Murray, R. Reash, \& T. Saltman (Eds.), Ecosystem responses to mercury contamination: Indicators of change (pp. 47-87). New York: Society of Environmental Toxicology and Chemistry (SETAC) North America Workshop on Mercury Monitoring and Assessment, CRC.

Yang, H., Rose, N. L., Battarbee, R. W., \& Boyle, J. F. (2002). Mercury and lead budgets for Lochnagar, a Scottish mountain lake and its catchment. Environmental Science and Technology, 36, 13831388. 